\title{
Effect of YAG Laser Cutting on Stretch-flangeability of Ultra High Strength TRIP Sheet Steel with Bainitic Ferrite Matrix
}

\author{
Akihiko NAGASAKA, ${ }^{1)}$ Yuichi KUBOTA, ${ }^{2)}$ Koh-ichi SUGIMOTO, ${ }^{3)}$ Atsushi MIO, ${ }^{4)}$ Tomohiko HOJO, ${ }^{5)}$ \\ Koichi MAKII, ${ }^{6)}$ Masahiro KAWAJIRI ${ }^{2)}$ and Mitsunari KITAYAMA ${ }^{1)}$
}

1) Department of Mechanical Engineering, Nagano National College of Technology, 716 Tokuma, Nagano, Nagano $381-8550$ Japan. E-mail: nagasaka@me.nagano-nct.ac.jp Tokuma, Nagano, Nagano 381-8550 Japan.

2) Advanced Courses, Nagano National College of Technology, 716 4-17-1 Wakasato, Nagano, Nagano 380-8553 Japan.

3) Department of Mechanical Systems Engineering, Shinshu University, 716 Tokuma, Nagano, Nagano 381-8550 Japan.

5) Department of Mechanical Engineering, Tsuyama National College of Technology, 624-1 Numa, Tsuyama, Okayama 708-8509 Japan. Group, Kobe Steel, Ltd., 27-8 Prime Central Tower, 2-Meieki, Nishi-ku Nagoya, Aichi 451-0045 Japan.

(Received on September 29, 2009; accepted on July 5, 2010; originally published in Tetsu-to-Hagané, Vol. 94, 2008, No. 9, pp. 351-356)

\begin{abstract}
The effect of YAG laser cutting on stretch-flangeability of ultra high strength TRIP-aided steel sheets with bainitic ferrite matrix (TBF steel sheet) austempered at 375 or $450^{\circ} \mathrm{C}$, was investigated for automotive applications. Holes of $5 \mathrm{~mm}$ diameter for hole-expanding test were produced by YAG laser cutting and mechanical punching and the stretch-flangeability was evaluated by measurement of the hole-expanding ratio $(\lambda)$.

In TBF steel sheet, laser cut specimens show higher stretch-flangeability than mechanically punched specimens. The hole-expanding ratio $(\lambda)$ of TBF steel sheet austempered at $375^{\circ} \mathrm{C}$ in the case of laser cutting at powers between 50 and $100 \mathrm{~W}$ was higher than those austempered at $450^{\circ} \mathrm{C}$. Furthermore, the strength-stretch-flangeability balance $(T S \times \lambda)$ of TBF steel sheet austempered at $375^{\circ} \mathrm{C}$ showed the highest value after laser cutting at $100 \mathrm{~W}$. Compared to mechanical punching, YAG laser cutting contributed to the improvement of the $T S \times \lambda$ to $1100 \mathrm{MPa}$ with TBF steel sheet possessing fine bainitic ferrite matrix.
\end{abstract}

KEY WORDS: YAG laser cutting; TRIP-aided steel sheet; stretch-flangeability; retained austenite; transformation-induced plasticity; TBF steel sheet; bainitic ferrite matrix.

\section{Introduction}

Increasingly, weight reduction for fuel efficiency due to environmental pressures, and the improvement of crash safety, to defend the driver are requirements in the car industry. Therefore, steel that is thin and high strength with formability is highly desirable. As TRIP-aided steels possess excellent press formability, a great deal of research has been undertaken attempting to apply these steels to member parts, seat rails and automotive underbody parts such as lower arms.

On the other hand, the stretch-flangeability of the TRIPaided steels is lower than the other properties of press formability, but can be improved by warm forming ${ }^{1,2)}$ and microstructure control. ${ }^{3)}$

There are two kinds of lasers (YAG laser and $\mathrm{CO}_{2}$ laser) widely used in industry. YAG laser of $1.06 \mu \mathrm{m}$ wavelength has several differences from $\mathrm{CO}_{2}$ laser of $10.6 \mu \mathrm{m}$ wavelength. ${ }^{4)}$ The difference of the energy absorption rate of the metal depends on the wavelength of laser. The energy absorption rate of the steel using YAG laser, due to wavelength being shorter by one order of magnitude, is about four times of that using $\mathrm{CO}_{2}$ laser. In laser cutting of steel, the total energy input into the workpiece with a high absorption rate of YAG laser is lowered due to smaller melting zone. The YAG laser is suitable for the cutting and welding of the steel sheets to microscopic precision due to this low power. ${ }^{4)}$ Research on the improvement of $\mathrm{CO}_{2}$ laser cutting on stretch-flangeability of steel sheet has been reported, ${ }^{5,6}$ however there have been few investigations of the effect of YAG laser on cutting TRIP-aided steel sheet. ${ }^{7,8)}$ The improvement by laser cutting of ultra high strength steel sheets with strength level of $980 \mathrm{MPa}$ or higher has not been previously achieved. The maximum power of available laser is always increasing, however laser cutting with the low power is often desirable due to the greater efficiency.

In this investigation, the effect of YAG laser cutting on stretch-flangebility of TRIP-aided steel sheet with bainitic ferrite matrix (TBF steel) is studied.

\section{Experimental Procedure}

Table 1 shows the chemical composition of steel sheets used in this study, and Fig. 1 shows the heat treatment diagram. Cold-rolled steel sheets (thickness: $1.2 \mathrm{~mm}$ ) with 
Table 1. Chemical composition of steel sheets used (mass $\%$ ).

\begin{tabular}{|l|cccccc|}
\hline steel & $\mathrm{C}$ & $\mathrm{Si}$ & $\mathrm{Mn}$ & $\mathrm{P}$ & $\mathrm{S}$ & $\mathrm{Al}$ \\
\hline TBF & 0.20 & 1.51 & 1.51 & 0.015 & 0.0011 & 0.040 \\
TDP1 & 0.10 & 1.49 & 1.50 & 0.015 & 0.0012 & 0.038 \\
TDP2 & 0.20 & 1.51 & 1.51 & 0.015 & 0.0011 & 0.040 \\
TDP3 & 0.29 & 1.46 & 1.50 & 0.014 & 0.0012 & 0.043 \\
TDP4 & 0.40 & 1.49 & 1.50 & 0.015 & 0.0012 & 0.045 \\
MDP & 0.14 & 0.21 & 1.74 & 0.013 & 0.0030 & 0.037 \\
\hline
\end{tabular}
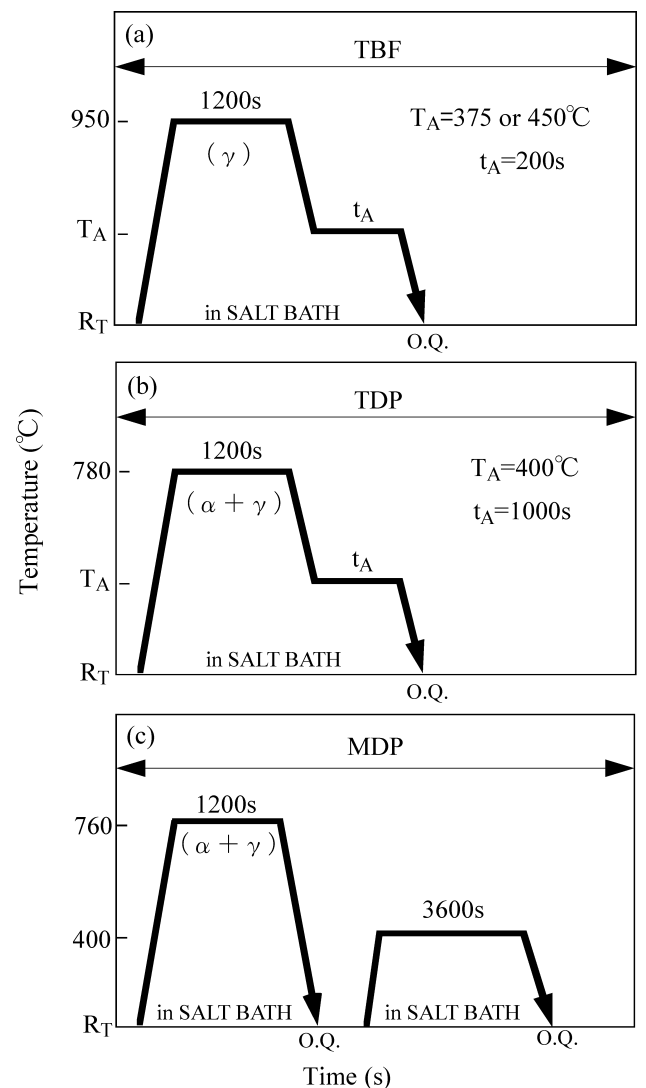

Fig. 1. Heat treatment diagram, in which "O.Q.", "A.C" and " $\mathrm{R}_{\mathrm{T}}$ " represent quenching in oil, air cooling and room temperature, respectively.

chemical composition of Table 1 were prepared. The TBF steel sheets were austempered at $T_{\mathrm{A}}=375$ or $450^{\circ} \mathrm{C}$ for $200 \mathrm{~s}$ in salt bath after annealing at $950^{\circ} \mathrm{C}$ for $1200 \mathrm{~s}$, as shown in Fig. 1(a). Hereafter, these steel sheets are named TBF375 or TBF450. The temperature around martensitestart temperature $\left(M_{\mathrm{S}}\right)$ was applied as austempering temperatures. $M_{\mathrm{S}}$ of the TBF steel sheet was estimated as $420^{\circ} \mathrm{C}$ using the following equation. ${ }^{9)}$

$$
\begin{aligned}
M_{\mathrm{S}}\left({ }^{\circ} \mathrm{C}\right)= & 550-361 \times(\% \mathrm{C})-394(\% \mathrm{Mn})-0 \times(\% \mathrm{Si}) \\
& +30 \times(\% \mathrm{Al})-5 \times(\% \mathrm{Mo}) \ldots \ldots \ldots \ldots \ldots \ldots \ldots \ldots \ldots \ldots \ldots \ldots \ldots \ldots \ldots \ldots
\end{aligned}
$$

For comparison with TBF steel sheet, TRIP-aided steel sheets with polygonal ferrite matrix (TDP steel) austemperd at $400^{\circ} \mathrm{C}$ for $1000 \mathrm{~s}$ after intercritical annealing at $780^{\circ} \mathrm{C}$ for $1200 \mathrm{~s}$, as shown in Fig. 1(b), were prepared. The TDP steel sheets contained similar silicon and manganese percentage, and carbon was in the range of 0.1 to 0.4 mass $\%$. Hereafter, these steel sheets are named TDP1 to TDP4. The ferrite martensite dual-phase (MDP) steel sheet that did not contain retained austenite $\left(\gamma_{R}\right)$ was also prepared (Fig. 1(c)).

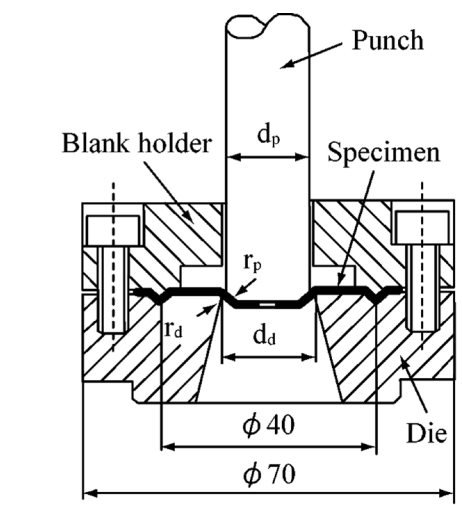

( $\left.d_{p}=17.4 \mathrm{~mm}, r_{p}=3.0 \mathrm{~mm}, d_{d}=22 \mathrm{~mm}, r_{d}=1 \mathrm{~mm}\right)$

Fig. 2. Experimental apparatus for hole-expanding.

Tensile testing was performed on an Instron type of tensile testing machine at a crosshead speed of $1 \mathrm{~mm} / \mathrm{min}$ (strain rate: $2.8 \times 10^{-4} / \mathrm{s}$ ), using JIS-13B type tensile specimens.

Hole-expanding test was carried out using disc specimens of $50 \mathrm{~mm}$ in diameter and experimental apparatus illustrated in Fig. 2. A hole of $5 \mathrm{~mm}$ in diameter was produced by laser cutting or mechanical punching. The test was performed using a flat-bottom punch at a speed of 1 $\mathrm{mm} / \mathrm{min}$.

Laser cutting was performed on a YAG laser equipment with maximum average output of $350 \mathrm{~W}$, and maximum peak output of $4.5 \mathrm{~kW}$. The laser cutting was operated at average powers between $P=25$ and $100 \mathrm{~W}$, (pulse energy of between $E=1$ and $4 \mathrm{~J} / \mathrm{P}$, pulse width of $2 \mathrm{~ms}$, and frequency of $25 \mathrm{~Hz}$ ), and cutting speed of $100 \mathrm{~mm} / \mathrm{min}$, with assist gas $(0.5 \mathrm{MPa})$ of oxygen. The laser cutting was performed at an angle of $45^{\circ}$ to the rolling direction. ${ }^{5}$ Mechanical punching was carried out on an Instron type of tensile testing machine with a graphitic lubricant, using a bush hole of 5.0 $\mathrm{mm}$ in diameter and a punch of $4.76 \mathrm{~mm}$ in diameter, at a punch rate of $10 \mathrm{~mm} / \mathrm{min}$, with a clearance of $10 \%$ between die and punch.

The stretch-flangeability was evaluated by tha hole-expanding ratio $(\lambda)$ expressed by

$$
\lambda=\frac{d_{f}-d_{0}}{d_{0}} \times 100 \%
$$

where the $d_{0}$ and $d_{f}$ are an initial hole diameter and a diameter on cracking, respectively.

The amount of retained austenite was quantified by X-ray diffractometry using Mo- $\mathrm{K}_{\alpha}$ radiation. The initial volume fraction of retained austenite $\left(f_{\gamma 0}\right)$ was quantified on the basis of the integrated intensity of $(200)_{\alpha},(211)_{\alpha},(200)_{\gamma}$, $(220)_{\gamma}$ and $(311)_{\gamma}$ diffraction peaks, termed the five-peak method. ${ }^{10)}$ The retained austenite lattice constant $\left(a_{\gamma}\right)$ was measured from $(220)_{\gamma}$ diffraction peak using $\mathrm{Cr}-\mathrm{K}_{\alpha}$ radiation. Substituting the measured $a_{\gamma}$ value (nm) into the following equation, carbon concentration of the retained austenite $\left(C_{\gamma 0}, \operatorname{mass} \%\right)$ was calculated. ${ }^{11)}$

$$
C_{\gamma 0}=\left(a_{\gamma}-0.35467\right) / 4.67 \times 10^{-3}
$$

Hardness was measured with the dynamic ultra microVickers hardness tester and was evaluated with a dynamic 

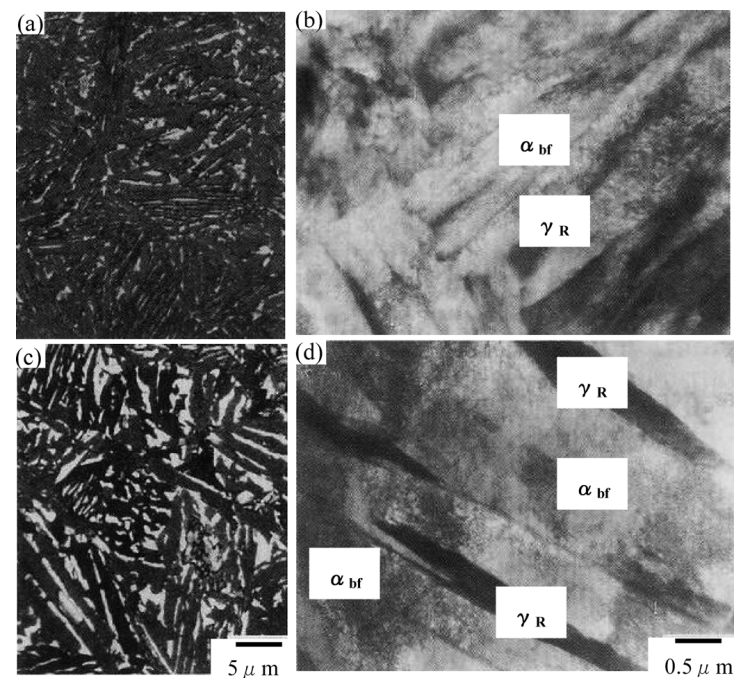

Fig. 3. Optical and transmission electron micrographs of TBF steel sheet austempered at (a)-(b) $375^{\circ} \mathrm{C}$ or (c)-(d) $450^{\circ} \mathrm{C}$, in which " $\gamma_{R}$ " and " $\alpha_{b f}$ " denote retained austenite film and bainitic ferrite matrix, respectively. In (a) and (c), white and gray regions represent retained austenite and/or martensite and bainitic ferrite matrix, respectively. (a) and (c): RePera etching.

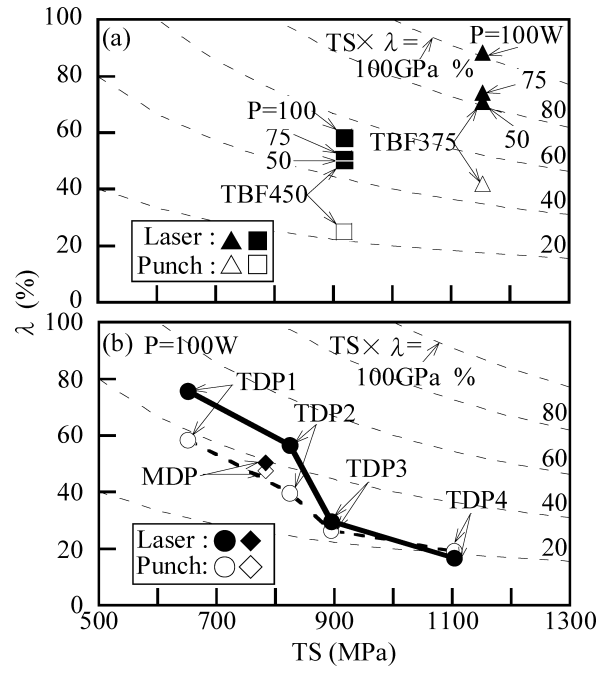

Fig. 4. Comparison of hole-expanding ratio $(\lambda)$ as a function of tensile strength $(T S)$, in which marks represent punching (open marks) and laser cutting (solid marks), respectively.

Table 2. Retained austenite characteristics and tensile properties of steel sheets used.

\begin{tabular}{|c|c|c|c|c|c|c|c|c|c|c|}
\hline steel & $\begin{array}{c}T_{\mathrm{A}} \\
\left({ }^{\circ}\right)\end{array}$ & $\begin{array}{c}f \\
(\mathrm{vol} \%)\end{array}$ & $\begin{array}{c}f_{\alpha \mathrm{m}} \\
(\mathrm{vol} \%)\end{array}$ & $\begin{array}{c}f_{\gamma 0} \\
(\mathrm{vol} \%)\end{array}$ & $\begin{array}{c}C_{\gamma 0} \\
(\mathrm{mass} \%)\end{array}$ & $\begin{array}{c}Y S \\
(\mathrm{MPa})\end{array}$ & $\begin{array}{c}T S \\
(\mathrm{MPa})\end{array}$ & $\begin{array}{c}U E l \\
(\%)\end{array}$ & $\begin{array}{c}T E l \\
(\%)\end{array}$ & $\begin{array}{c}R A \\
(\%)\end{array}$ \\
\hline TBF375 & 375 & 8.9 & 0 & 8.9 & 1.16 & 971 & 1154 & 4.4 & 7.8 & 40.3 \\
\hline TBF450 & 450 & 19.3 & 8.1 & 11.2 & 0.96 & 617 & 918 & 14.2 & 18.2 & 44.5 \\
\hline TDP1 & 400 & 19.9 & 0 & 4.9 & 1.31 & 429 & 651 & 27.8 & 37.2 & 49.2 \\
\hline TDP2 & 400 & 35.3 & 0 & 9.0 & 1.38 & 526 & 825 & 31.7 & 36.0 & 44.0 \\
\hline TDP3 & 400 & 44.1 & 0 & 13.2 & 1.41 & 562 & 895 & 28.6 & 32.2 & 41.8 \\
\hline TDP4 & 400 & 55.1 & 0 & 17.0 & 1.45 & 728 & 1103 & 29.2 & 32.8 & 41.8 \\
\hline MDP & - & 27.1 & 27.1 & - & - & 593 & 783 & 8.3 & 13.1 & 44.5 \\
\hline
\end{tabular}

$T_{\mathrm{A}}$ : austempering temperature, $f, f_{\alpha \mathrm{m}}, f_{\gamma 0}$ : initial volume fraction of second phase, martensite and retained austenite, $C_{\gamma 0}$ : initial carbon concentration of retained austenite, $Y S$ : yield stress or $0.2 \%$ offset proof stress, $T S$ : tensile strength, $U E l$ : uniform elongation, $T E l$ : total elongation and $R A$ : reduction of area.

hardness $^{12)}(D H V)$. The dynamic hardness was calculated from the indentation force $(F)$ and depth $(h)$ using the following equation (load: $F=9.81 \mathrm{mN}$, load speed: $1.42 \mathrm{mN} / \mathrm{s}$ ).

$$
D H V=3.858 F / h^{2}
$$

\section{Results and Discussion}

\subsection{Microstructure and Tensile Properties}

Figure 3 shows typical micrographs of the TBF steel sheet. Figures 3(a) and 3(b) show the microstructure of TBF375, and Figs. 3(c) and 3(d) show the microstructure of TBF450, etched by LePera reagent. In these photographs, white regions represent retained austenite $\left(\gamma_{R}\right)$ and/or martensite $\left(\alpha_{m}\right)$ and gray regions represent bainitic ferrite matrix $\left(\alpha_{b f}\right)$. Table 2 shows the second phase characteristics, the $\gamma_{R}$ characteristics and the tensile properties of the steel sheets after heat-treatment. The microstructure of TBF375 steel austempered at $375^{\circ} \mathrm{C}$, which is below the $M_{\mathrm{S}}$ $\left(420^{\circ} \mathrm{C}\right)$ of this steel mainly consists of bainitic ferrite lath matrix $\left(\alpha_{b f}\right)$ and interlath retained austenite films $\left(\gamma_{\mathrm{R}}\right)^{2)}$ Bainitic ferrite lath is similarly assumed to be the matrix in TBF450 austempered at $450^{\circ} \mathrm{C}$ with $\alpha_{m}$ of $8.1 \mathrm{vol} \%$ but without $\gamma_{R}$ as the second phase (Table 2). The initial volume fraction $\left(f_{\gamma 0}\right)$ of $\gamma_{R}$ of TBF450 increases compared with TBF375. ${ }^{2}$ In addition the tensile strength (TS) of TBF375 is higher than that of TBF450 reaching $1100 \mathrm{MPa}$.

\subsection{Stretch-flangeability}

Figure 4 shows the relation between hole-expanding ratio $(\lambda)$ and tensile strength $(T S)$. Laser cutting with the average power $P=100 \mathrm{~W}$ is carried out on non-TBF steel sheets. In comparison to the case of mechanical punching in Fig. 4(a), the $\lambda$ s of both TBF steel sheets have high value instead of high TS. Varying the average power of laser cutting, the $\lambda_{\mathrm{s}}$ of both TBF steel sheets when $P=100 \mathrm{~W}$ indicate a higher value than when $P=50 \mathrm{~W}$, and $P=25 \mathrm{~W}$ was not sufficient for laser cutting. On the other hand, the holeexpanding ratio $(\lambda)$ of laser cutting and mechanical punching decreases, and the tensile strength $(T S)$ is higher when the carbon content is increased from 0.1 to 0.4 mass $\%$ in the TDP steel sheets (Table 2).

The $\lambda$ following laser cutting decreases in comparison to that after mechanical punching when the carbon content is above 0.3 mass $\%$. In the MDP steel sheet, laser cutting and mechanical punching result in the same $\lambda$. 


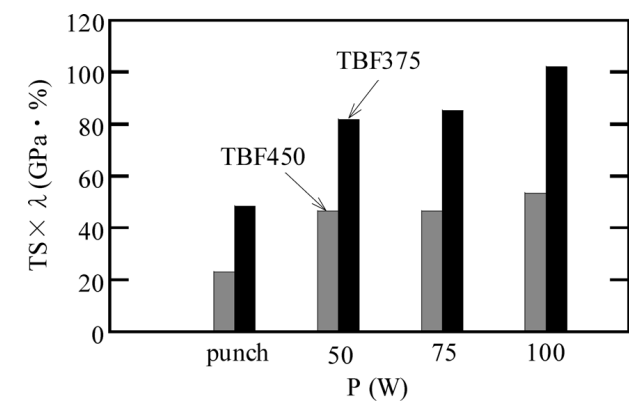

Fig. 5. Comparison between strength-stretch-flangeability balance $(T S \times \lambda)$ and average power $(P)$.
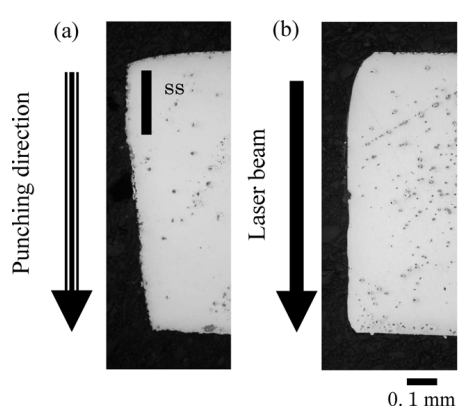

Fig. 6. Optical micrographs of cross-section of TBF450 steel with (a) hole-punching and (b) laser cutting.

The index of stretch-flangeability, the product of tensile strength $(T S)$ and hole-expanding ratio $(\lambda)$ (i.e. strengthstretch-flangeability balance $(T S \times \lambda))$ and average power $(P)$ of the TBF steel sheet are compared in Fig. 5. With average power $P=100 \mathrm{~W}, T S \times \lambda$ of TBF375 has an excellent result of $100 \mathrm{GPa} \%$, higher value than $\mathrm{TBF} 450$. It is considered that TBF steel sheet (TBF375) austempered below the $M_{\mathrm{S}}$ exhibited remarkable formability after laser cutting due to the fine microstructure present (Fig. 3(a)). The fine microstructure is considered to provide resistance to crack initiation and propagation.

\subsection{Mechanism of Stretch-flangeability Improvement by Laser Cutting}

Figure 6 shows optical micrographs of the cross-sections of TBF steel sheets after mechanical punching and laser cutting. In TBF450, Fig. 6(a) shows the cross-sections of steel with mechanical punching and Fig. 6(b) shows those of the same specimens after laser cutting with the average power $P=100 \mathrm{~W}$.

In general, in the case of mechanical punching, a rollover portion $(r p)$, shearing section ( $s s)$ and break section $(b s)$ are formed along the direction of punching. Figure 7 shows the relationship between ratio of roll-over portion $(r p)$, shearing section $(s s)$ and break section $(b s)$ of TDP and TBF steel sheets. In TDP steel sheet, when the carbon content increases, the shearing section (ss) length decreases. The length of break section $(b s)$ increases due to decreasing to $\lambda$ value. Break section $(b s)$ of TBF375 and TBF450 is equal to break section (bs) of TDP2 steel sheet, and shearing section $(s s)$ is maintained while the steel also possesses ultra high strength.

On the other hand, the specimens subjected to laser cutting have no remarkable differences in $r p$, ss or $b s$. No clear difference is not observed in the cross-section of TBF

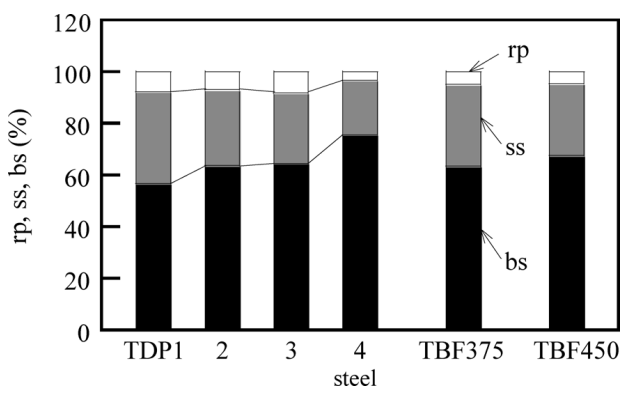

Fig. 7. Relationship between ratio of roll-over portion ( $r p$ ), shearing section ( $s s)$ and break section $(b s)$, and TDP and TBF steel sheets.
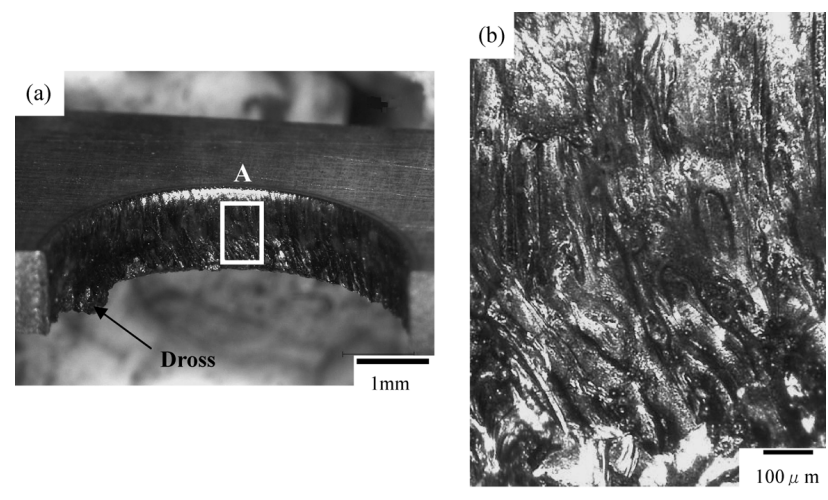

Detail of $A$

Fig. 8. Photographs of outside and cross-section area of TFB375 steel sheet with laser cutting $(P=100 \mathrm{~W})$.

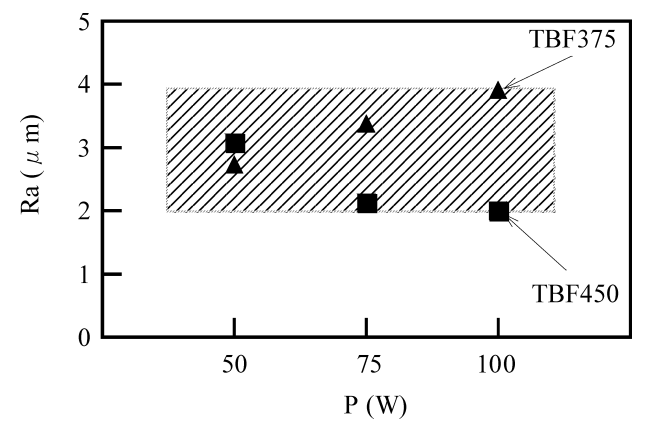

Fig. 9. Relation between surface roughness (Ra) and average power $(P)$.

steel sheets after laser cutting as a result of avarage laser power (Fig. 6(b)).

\subsection{The Surface Roughness on the Cross-Sections of Laser Cutting}

Figure 8 shows the photographs of outside and crosssection area of TBF375 steel sheet with laser cutting. In TBF375 of $P=100 \mathrm{~W}$, the laser beam is positioned above the sheet and dross is deposited on the under surface of the steel. Similar dross was generated in $P=50-75 \mathrm{~W}$.

Figure 9 shows the relation between the surface roughness $(\mathrm{Ra})$ and average power $(P)$. Roughness is evaluated using the laser scanning microscope. The magnification is 400 times, and the offset of $R \mathrm{a}$ is $0.25 \mathrm{~mm}$. $R \mathrm{a}=2-4 \mu \mathrm{m}$ and doesn't depend on the change in the average power.

\subsection{Microstructure on Cross-Section of Laser Cutting}

Figure 10 shows the scanning electron micrograph of 


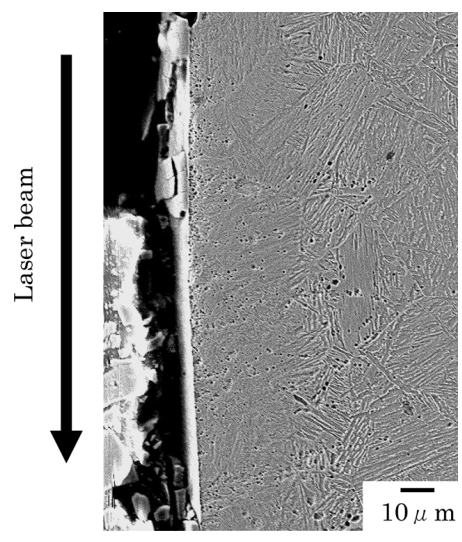

Fig. 10. Scanning electron micrograph of cross-section of TBF375 steel sheet with laser cutting $(P=100 \mathrm{~W})$.

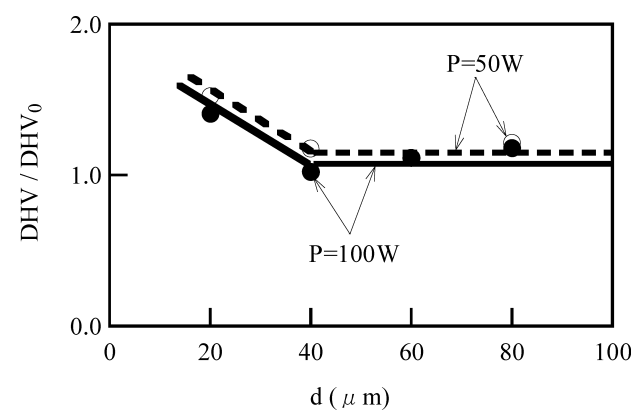

Fig. 11. Variation in dynamic hardness ratio $\left(D H V / D H V_{0}\right)$ at the section of distance $(d)$ in TBF375 steel sheet.

cross-section of TBF375 with laser cutting. In TBF375, the microstructure to a depth about $30 \mu \mathrm{m}$ becomes fine as a result of the laser cutting. It is considered that the $\lambda$ value is improved in comparison to the mechanical punching which formed the detrimental processing affected layer.

Especially, it is considered that fineness of the microstructure in TBF375 is a factor mitigating early crack initiation in the steel after laser cutting or mechanical punching. ${ }^{13)}$

As for the microstructure of TBF450, the size of $\gamma_{R}$ is relatively larger and the initial carbon concentration of $\gamma_{R}$ $\left(C_{\gamma 0}\right)$ is lower (Table 2) than that of TBF375 (Fig. 3).

This causes decreased stability of $\gamma_{R}$, promoting greater transformation of $\gamma_{R}$ during deformation. It also causes the decrease in stretch-flangeability, and the $\lambda$ of TBF450 has decreased compared to TBF375 (Fig. 4(a)).

Figure 11 shows the variation in dynamic hardness ratio $\left(D H V / D H V_{0}\right)$ on direction of depth in the cross-section of laser cutting. Where, $D H V$ is dynamic hardness of crosssection of laser cutting, and $D H V_{0}$ is dynamic hardness of the base material. In TBF375, open marks are for the case of average power $P=50 \mathrm{~W}$ and solid marks are for $P=100 \mathrm{~W}$. When the hardness of heat-affected zone of $20 \mu \mathrm{m}$ and $40 \mu \mathrm{m}$ depth are compared, the hardness is decreased with increasing distance from the surface of crosssection and then the hardness of the base material is constant. A clear difference was not observed between average power $P=50 \mathrm{~W}$ and $P=100 \mathrm{~W}$ in TBF450.

Figure 12 shows the scanning electron micrographs of cross-section of TBF375 steel after laser cutting. Figure 12(a) is in the case of after laser cutting with the average power $P=50 \mathrm{~W}$ in TBF375, and Fig. 12(b) is in the case of
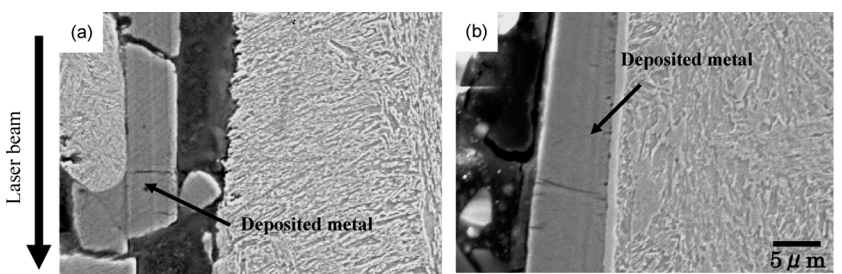

Fig. 12. Scanning electron micrographs of cross-section of TBF375 steel sheet with laser cutting ((a) $P=50 \mathrm{~W}$, (b) $P=100 \mathrm{~W})$.

$P=100 \mathrm{~W}$. A slightly rough surface can be observed in Fig. 12(a). The difference in the cross-section surface is observed by the difference between the average powers of laser cutting. This roughness creates a starting point for cracking during hole-expanding test, and it is considered that $\lambda$ of laser cutting of TBF375 is reduced in the range of low powered laser cutting (Fig. 4). The improvement of the $\lambda$ value by the low power laser cutting can be expected in the future, due to improvement of laser technology.

In general, the effect of TRIP of $\gamma_{R}$ has an important role to the improvement of stretch-flangeability in the case of warm forming ${ }^{1)}$ etc. It has been reported that in TDP steel sheet up to 0.2 mass $\% \lambda$ has been improved by YAG laser cutting, due to stable and a large amount $\gamma_{R}{ }^{1)}$. However, the improvement of $\lambda$ having a tensile strength of $980 \mathrm{MPa}$ grade could not be achieved. In consideration of the ductility of TRIP-aided steel sheet with bainitic ferrite matrix and different $M_{\mathrm{S}}$ achieved excellent local elongation, it is clarified that the stretch-flangeability is improved by the laser cutting, and the effect of the laser cutting on the stretchflangeability can be improved by controlling the laser power.

\section{Conclusions}

The effect of YAG laser cutting on stretch-flangeability of TRIP-aided steel sheet with bainitic ferrite matrix was investigated. The results are summarized as follows.

(1) The laser cutting greatly improves the stretchflangeability of ultra high strength in comparison to mechanical punching in TRIP-aided steel sheet with bainitic ferrite matrix (TBF steel).

(2) During hole-expanding test, the TBF steel sheet below $M_{\mathrm{S}}$ temperature (TBF375) enhanced the effect of the laser cutting due to the fine bainitic ferrite matrix, which improved the strength-stretch-flangeability balance $(T S \times \lambda$ : a product of tensile strength and hole-expanding ratio).

\section{Acknowledgements}

The authors wish to thank The Research Foundation for the Electrotechnology of Chubu, The Amada Foundation for Metal Work Technology and The Die and Mold Technology Promotion Foundation for their financial supports and K. Wada, G. Arai and S. Toya of Nagano National College of Technology.

\section{REFERENCES}

1) K. Sugimoto, A. Nagasaka, M. Kobayashi and S. Hashimoto: ISIJ Int., 39 (1999), 56.

2) K. Sugimoto, S. Song, J. Sakaguchi, A. Nagasaka and T. Kashima: 
ISIJ International, Vol. 50 (2010), No. 10

Tetsu-to-Hagané, 91 (2005), 278

3) K. Sugimoto, A. Kanda, R. Kikuchi, S. Hashimoto, T. Kashima and S. Ikeda: ISIJ Int., 42 (2002), 910.

4) Y. Kaneoka: Laser Processing, Nikkan Kogyo Shimbun, Tokyo, (1999), 5.

5) H. Shirasawa, S. Hashimoto, K. Mimura and K. Korida: Tetsu-toHagané, 16 (1985), 1949.

6) H. Hayashi, K. Tezen and T. Amaike: J. Jpn. Soc. Technol. Plast., 27 (1986), 984.

7) A. Nagasaka, K. Sugimoto, A. Koyama, S. Hashimoto, T. Kashima, T. Hojo and A. Mio: J. Jpn. Soc. Heat Treat., 46 (2006), 25.

8) A. Nagasaka, K. Sugimoto, Y. Kubota, A. Koyama, Y. Mukai and T.
Hojo: J. Jpn. Soc. Heat Treat., 47 (2007), 71.

9) I. Tamura: Steel Material Strength, Nikkan Kogyo Shimbun, Tokyo, (1970), 39.

10) H. Maruyama: J. Jpn. Soc. Heat Treat., 17 (1977), 198.

11) Z. Nishiyama: Martensite Transformation, Maruzen, Tokyo, (1979), 13.

12) Y. Yamamoto and T. Nishimura: Shimadzu Rev., 50 (1993), 320.

13) K. Sugimoto, M. Kobayashi, K. Inoue, X. Sun and S. Shiroda: Tetsuto-Hagané, 84 (1998), 559.

14) T. Nakagawa: Handbook of Press Forming Difficulty, Nikkan Kogyo Shimbun, Tokyo, (1997), 472. 